\title{
HUBUNGAN KEBIASAAN MENGGUNAKAN LAS LISTRIK DENGAN PENURUNAN KETAJAMAN PENGLIHATAN PADA PEKERJA BENGKEL LAS DI TORAJA UTARA TAHUN 2021
}

\author{
Atriani Maria Sappa ${ }^{1}$, Hotmaulina Sihotang ${ }^{2}$ \\ Pascasarjana Universitas Kristen Jakarta, Indonesia ${ }^{1,2}$ \\ atrimarsa@gmail.com ${ }^{1}$, hotmaulina.sihotang@uki.ac.id ${ }^{2}$
}

Received: 06-06-2021

Revised : 06-07-2021

Accepted: 25-07-2021

\begin{abstract}
Abstrak
Latar Belakang: Penurunan ketajaman penglihatan adalah ketidakmampuan mata dalam melihat objek secara jelas dan sangat bergantung pada kemampuan akomodasi mata.

Tujuan: Tujuan penelitian ini adalah untuk mengetahui Hubungan Kebiasaan Menggunakan Las Listrik dengan Penurunan Ketajaman Penglihatan pada Pekerja Bengkel Las Di Kabupaten Toraja Utara Tahun 2021.

Metode: Metode penelitian ini adalah deskriptif analitik dengan pendekatan cross sectional. Populasi dalam penelitian ini adalah pekerja bengkel las di Kabupaten Toraja Utara tahun 2021. Besarnya sampel 46 responden dengan menggunakan teknik total sampling. Pengumpulan data dilakukan dengan menggunakan lembaran kuesioner. Analisis data dilakukan dengan bantuan SPSS versi 23 menggunakan uji chi-Square dengan derajat kemaknaan $\mathrm{p}<0,05$.
\end{abstract}

Hasil: Hasil penelitian, responden yang memiliki kebiasaan menggunakan las listrik yang baik sebanyak 16 responden $(34,8 \%)$ dan responden dengan kebiasaan menggunakan las listrik yang buruk sebanyak 30 responden $(65,2 \%)$ dan responden yang memiliki ketajaman penglihatan normal sebanyak 8 responden $(17,4 \%)$ dan responden penurunan ketajaman penglihatan sebanyak 38 responden $(82,6 \%)$. Berdasarkan hasil uji statistik SPSS didapat hasil $\mathrm{p}=0,859$ $(\alpha<0,05)$. Artinya tidak ada hubungan kebiasaan menggunakan las listrik dengan penurunan ketajaman penglihatan pada pekerja bengkel las di Kabupaten Toraja Utara Tahun 2021 atau Ha ditolak dan Ho diterima.

Kesimpulan: Kesimpulan dari penelitian ini adalah tidak ada Hubungan Kebiasaan Menggunakan Las Listrik dengan Penurunan Ketajaman Penglihatan di Kabupaten Toraja Utara Tahun 2021. Di sarankan kepada pihak tenaga kesehatan Kabupaten Toraja Utara untuk memberikan pelayanan yang baik dan penyuluhan kepada pekerja Las dan masyarakat memeriksakan mata 6 bulan sekali.

Kata kunci: kebiasaan menggunakan las listrik; penurunan ketajaman penglihatan.

\section{Abstract}

Background: Decreased visual acuity is the inability of the 
eye to see objects clearly and is highly dependent on the accommodation ability of the eye.

Objective: The purpose of this study was to determine the relationship between the habit of using electric welding with a decrease in visual acuity in welding workshop workers in North Toraja Regency in 2021.

Methods: This research method is descriptive analytic with a cross sectional approach. The population in this study were welding workshop workers in North Toraja Regency in 2021. The sample size was 46 respondents using total sampling technique. Data was collected by using a questionnaire sheet. Data analysis was carried out with the help of SPSS version 23 using the chi-square test with a significance degree of $p<0.05$.

Results: The results of the study, respondents who have a good habit of using electric welding are 16 respondents $(34.8 \%)$ and respondents with bad habits of using electric welding are 30 respondents $(65.2 \%)$ and respondents who have normal visual acuity are 8 respondents (17.4\%) and respondents decreased visual acuity as many as 38 respondents (82.6\%). Based on the results of the SPSS statistical test, $p=0.859(\alpha<0.05)$. This means that there is no relationship between the habit of using electric welding with decreased visual acuity in welding workshop workers in North Toraja Regency in 2021 or Ha is rejected and Ho is accepted.

Conslusion: The conclusion of this study is that there is no relationship between the habit of using electric welding with a decrease in visual acuity in North Toraja Regency in 2021. It is recommended to the health workers of North Toraja Regency to provide good service and counseling to welding workers and the community for 6 months of eye exams. very.

Keywords: the habit of using electric welding; drop visual acuity.

Coresponden Author : Atriani Maria Sappa'

Email : atrimarsa@gmail.com

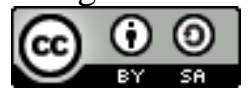

\section{PENDAHULUAN}

Ketajaman penglihatan atau visual acuity merupakan batas kemampuan untuk membedakan objek visual secara detil (Westheimer, 2010). Penurunan ketajaman penglihatan merupakan gangguan penglihatan dimana terjadi penurunnya luas lapang pandang yang dapat mengakibatkan kebutaan (RI, 2016).

Salah satu kondisi yang dapat menyebabkan terjadinya penurunan ketajaman penglihatan adalah akibat dari paparan sinar las tanpa menggunakan Alat Pelindung Diri (APD). Las listrik adalah suatu kegiatan yang menghubungkan dua logam dengan bantuan busur listrik. Las listrik adalah suatu proses menyambungkan logam dengan menggunakan tenaga listrik sebagai sumber panas. Jenis sambungan dengan las listrik adalah merupakan sambungan tetap. Pada pengelasan dengan las listrik, panas yang dihasilkan berasal dari busur listrik yang timbul dari menempelnya benda kerja dengan 
elektroda. Elektroda pengisian dipanaskan mencapai titik cair dan diendapkan pada sambungan, hingga terbentuk sambungan las. Panas yang dihasilkan oleh busur listrik mencapai $5500^{\circ} \mathrm{c}$. pada saat pengelasan menggunakan las listrik, dilepaskan energi dalam jumlah yang sangat besar dalam bentuk panas (Munarko, 2012).

Menurut Data (Rakasiwi \& Kep, 2019) saat ini terdapat 285.389 juta orang menderita gangguan kebutaan, $90 \%$ penderita mengalami Low Vision berada di Negara berkembang. penyebab terbanyak kebutaan di dunia adalah Katarak (51\%), Glukoma (8\%), Age-related Mucular Degeneration (AMD) (5\%) (Munadar \& Khairani, 2016).

Penurunan ketajaman penglihatan dan kebutaan di Indonesia terus mengalami peningkatan dengan prevalensi, $1,5 \%$ dimana angka ini merupakan angka tertinggi dibandingkan dengan angka kebutaan di negara-negara regional Asia Tenggara seperti Bangladesh sebesar $1 \%$, India sebesar $0,7 \%$, dan Thailand 0,3\%. Insiden kebutaan disetiap tahun yakni $0,1 \%$ (210.000 orang) (Kemenkes, 2013).

Prevalensi gangguan Penglihatan tertinggi di Sulawesi Utara $(3,7 \%)$ diikuti oleh Jambi $(2,8 \%)$ dan Bali (2,7\%). Prevalensi terendah di temukan di DKI Jakarta sebesar $(0,9 \%)$ dan $(1,1 \%)$ di Sulawesi Barat (KemenKes, 2013)).

Perhimpunan Dokter Spesialis Mata Indonesia (PERDAMI) yang mengadakan bakti sosial nasional di Toraja Utara bekerja sama dengan Himpunan Masyarakat Toraja Indonesia (PMTI), berhasil melakukan operasi katarak atau gangguan kebutaan pada 62 pasien dari 82 orang warga yang melakukan screening mata, 62 diantaranya dilakukan operasi katarak (Mumtaza, n.d.). Paparan sinar dalam waktu lama dapat merusak kesehatan mata, terutama pengaruh sinar infra merah yang mengakibatkan pembekakan kelopak mata, penyakit kornea, presbiopia dini dan kerabunan terutama terjadi pada pekerja pengelasan (Pratiwi, 2014).

Gangguan kesehatan mata yang terjadi antara lain penglihatan kabur, mata merah, mata terasa gatal, mata terasa perih, mata bengkak, mata sakit, mata berair, sakit kepala diatas mata, dan mata terasa seperti kelilipan (Priyanto \& Tarwaka, 2016).

Dari hasil survei awal yang dilakukan dengan teknik wawancara pada 10 orang pekerja las mengemukakan beberapa keluhan seperti merasakan kelelahan pada mata setelah melakukan pengelasan, mata nyeri, keluar air mata atau berair, mata kelilipan terasa kemasukan pasir, mata kabur setelah melakukan pengelasan, wajah terasa panas, mata silau seperti melihat cahaya putih. Pada masing-masing bengkel las saat melakukan pekerjaan pengelasan pekerja menggunakan kaca mata gelap biasa sebagai pelindung mata dan kadang mengabaikan alat pelindung diri.

Berdasarkan uraian yang dipaparkan diatas maka penulis tertarik melakukan penelitian mengenai kebiasaan menggunakan las listrik dengan penurunan ketajaman penglihatan pada pekerja bengkel las di kabupaten Toraja Utara karena kesehatan kerja dalam usaha sektor informal belum terpantau dengan baik.

\section{METODE PENELITIAN}

Desain penelitian yang digunakan oleh penelitian adalah desain deskriptif analitik (Hidayat, 2015). Desain deskriptif analitik digunakan untuk mengetahui hubungan antara dua variable. Penelitian menggunakan desain deskriptif analitik Karena ingin mengetahui Hubungan Kebiasaan Menggunakan Las Listrik dengan Penurunan Ketajaman Penglihatan Pada Pekerja Bengkel Las Di Kabupaten Toraja Utara. Penelitian dilakukan dengan pendekatan cross sectional yakni mengumpulkan data variable dependen dan independen hanya satu kali pada waktu yang sama tanpa ada tindak lanjut (Fazriah, 2018). 


\section{HASIL DAN PEMBAHASAN}

\section{A. Hasil Penelitian}

Penelitian ini menggunakan rancangan penelitian dengan rancangan kuantitatif dengan pendekatan cross sectional study, dimana subjek diukur pada suatu sampel populasi yang representatif dengan tujuan melihat hubungan kebiasaan menggunakan las listrik dengan penurunan ketajaman penglihatan pada pekerja bengkel las di Kabupaten Toraja Utara.

Penelitian ini dilakukan di Kabupaten Toraja Utara. Hasil penelitian ini diperoleh melalui teknik penyebaran kuesioner dan observasi kepada pekerja las listrik di beberapa tempat bengkel las di Kabupaten Toraja Utara.

Setelah data terkumpul dilakukan pemeriksaan kelengkapan dan kemudian data diolah, maka berikut ini penelitian akan menyajikan analisa data univariat terhadap setiap variabel menghasilkan distribusi frekuensi dan presentasi serta analisa bivariat untuk mengetahui hubungan dari variabel dependen dan independen menggunakan uji statistic chi-square dengan program SPSS VERSI 23.

1. Analisa Univariat

a. Kebiasaan Menggunakan Las Listrik

Tabel 1

Distribusi Responden Berdasarkan Kebiasaan

Menggunakan Las Listrik Di Kabupaten Toraja Utara Tahun 2021

$\begin{array}{lll}\text { Kebiasaan Menggunakan Las Listrik } & \text { Frekuensi (n) } & \text { Persentase (\%) }\end{array}$

\begin{tabular}{rrr}
\hline Baik & 16 & 34,8 \\
Buruk & 30 & 65,2 \\
\hline Total & $\mathbf{4 6}$ & $\mathbf{1 0 0 . 0}$ \\
\hline
\end{tabular}

Sumber: Data primer, 2021

Tabel 1 menunjukan distribusi frekuensi responden menurut kebiasaan menggunakan las listrik dari 46 responden didapatkan jumlah responden dengan kebiasaan buruk yaitu sebagian besar sebayak 30 orang $(65,2 \%)$ dan kebiasaan yang baik yaitu sebagian mayoritas sebanyak 16 orang $(34,8 \%)$.

b. Penurunan Ketajaman Penglihatan

Tabel 2

Distribusi Responden Berdasarkan

Penrunan Ketajaman Penglihatan Di Kabupaten Toraja Utara 2021

\begin{tabular}{lcc}
\hline \multicolumn{1}{c}{ Nilai visus } & $\begin{array}{c}\text { Frekuensi } \\
(\mathbf{n})\end{array}$ & Persentase (\%) \\
\hline Ketajaman penglihatan normal & 8 & 17,4 \\
Penurunan Ketajaman penglihatan & 38 & 82,6 \\
\hline
\end{tabular}

\begin{tabular}{ccc}
\hline Total & $\mathbf{4 6}$ & $\mathbf{1 0 0 , 0}$ \\
\hline & Sumber: Data primer, 2021 &
\end{tabular}

Berdasarkan Tabel 2 menunjukan distribusi frekuensi responden menurut penurunan ketajamn penglihatan dari hasil penelitian didapatkan jumlah responden dengan penurunan ketajaman penglihatan sebagian besar 38 orang $(82,6 \%)$ dan ketajaman penglihatan normal yaitu sebagian kecil sebanyak 8 orang $(17,4 \%)$. 
2. Analisa Bivariat

a. Hubungan Kebiasaan Menggunakan Las Listrik dengan Penurunan ketajaman Penglihatan di Kabupaten Toraja Utara Tahun 2021

Tabel 3

Hubungan Kebiasaan Menggunakan Las Listrik Dengan Penurunan Ketajaman Penglihatan di Kabupaten Toraja Utara Tahun 2021 Penurunan ketajaman penglihatan

$\begin{array}{cllll}\begin{array}{c}\text { Kebiasaan } \\ \text { menggunakan } \\ \text { las listrik }\end{array} & \begin{array}{l}\text { Ketejaman } \\ \text { penglihatan } \\ \text { normal }\end{array} & \begin{array}{l}\text { Penurunan } \\ \text { ketajaman } \\ \text { penglihatan }\end{array} & \text { Total } & \text { P } \\ & & & \end{array}$

\begin{tabular}{ccccccc} 
& $\mathrm{n}$ & $\%$ & $\mathrm{n}$ & $\%$ & $\mathrm{n}$ & $\%$ \\
\hline Baik & 3 & $6,5 \%$ & 13 & $28,3 \%$ & 16 & $34,8 \%$ \\
\hline Buruk & 5 & $10,9 \%$ & 25 & $54,3 \%$ & 30 & 65,2 \\
\hline Total & $\mathbf{8}$ & $\mathbf{1 7 , 4 \%}$ & $\mathbf{3 8}$ & $\mathbf{8 2 , 6 \%}$ & $\mathbf{4 6}$ & $\mathbf{1 0 0 , 0 \%}$ \\
\hline \multicolumn{7}{c}{ Sumber: Data primer 2021}
\end{tabular}

Berdasarkan Tabel 3 menunjukan responden dengan kebiasaan menggunakan las listrik yang buruk sebanyak 30 orang $(65,2 \%)$ diantaranya yang memiliki penurunan ketajaman penglihatan sebanyak 25 orang $(54,3 \%)$, yang memiliki ketajaman penglihatan normal sebanyak 5 orang $(10,9 \%)$. sedangkan responden dengan kebiasaan menggunakan las listrik yang baik sebayak 16 orang $(34,8 \%)$ diantaranya yang memiliki penurunan ketajaman penglihatan sebanyak 13 orang $(28,3 \%)$ dan yang memiliki ketajaman penglihatan normal sebanyak 3 oarang $(6,5 \%)$.

Berdasarkan analisis Uji chi-quare diperoleh nilai $\mathrm{p} 1,000$ dimana $\mathrm{p}>\alpha$. Hal ini berarti Ha ditolak Ho di terima atau Tidak Ada Hubungan Kebiasaan Menggunakan Las Listrik dengan Penurunan Ketajaman Penglihatan Pada Pekerja Bengkel Las Di Kabupaten Toraja Utara Tahun 2021.

Dari hasil analisa juga diperoleh nilai Odds Ratio 1,154 dengan tingkat kepercayaan $95 \%$ yang berarti responden dengan kebiasaan menggunakan las listrik baik memiliki peluang 1,154 untuk kebiasaan baik dibandingkan responden kebiasaan yang buruk.

\section{B. Pembahasan}

Setelah data dikumpulkan dan dikelola, berikut ini akan dilakukan pembahasan hasil penelitian sesuai variable yang diteliti adalah sebagai berikut :

1. Kebiasaan Menggunakan Las Listrik

Dari hasil penelitian ini menunjukan distribusi responden sebagai berikut, dari total 46 orang responden didapatkan 30 orang $(65,2 \%)$ yang memiliki kebiasaan menggunakan las listrik yang buruk. Hal ini disebabkan karena terdapat beberapa Pekerja tidak disiplin menggunakan APD. Kesadaran pekerja dalam memakai alat pelindung diri itu sangat penting, guna mencegah terjadinya penyakit yang timbul dikemudian hari akibat pekerjaan. Alasan pekerja tidak memakai alat pelindung dikarenakan ketidaknyamanan dalam bekerja. Oleh karena itu dibutuhkan peraturan dan kebiasaan diri dalam pemakaian alat pelindung diri sehingga pekerja sendiri terhindar dari paparan sinar ultraviolet, radiasi dari proses pengelasan yang dapat mengganggu kesehatan mata pekerja itu sendiri

Menurut (Larik et al., 2016) mengatakan bahwa alat elektronik modern memiliki pengaruh negative terhadap lensa mata. Protein pada lensa berubah sehingga dapat mengganggu ketajaman penglihatan. Paparan gelombang elektromagnetik menyebabkan 
perubahan pada protein lensa sehingga merubah struktur sel epitel pada lensa kerusakan pada enzim glutation peroksidase, yang bersifat sebagai pelindung lensa dari paparan radiasi.

Selain itu (Ramamurthy et al., 2015) mengatakan bahwa pekerja las pastinya berpotensi menimbulkan bahaya kecelakaan, baik jangka pendek maupun jangka panjang, begitu juga pada proses pengelasan, potensi bahaya yang dapat muncul. Kebiasaan menggunakan las listrik yang baik adalah Pencegahan dapat menggunakan alat pelindung diri seperti sarung tangan, apron, sepatu tahan api, kacamata las, dan alat pelindung wajah (face shield). Bekerja dengan menatap objek secara dekat juga berhubungan dengan kejadian miopia. Bukti terbaru mengatakan bahwa instensitas menatap jarak dekat yang dipertahankan sengan jarak kurang dari $30 \mathrm{~cm}$ dengan jeda yang singkat lebih penting disbanding lama waktu menatap jarak dekat.

Pada distribusi frekuensi responden dengan variabel kebiasaan menggunakan las listrik didapatkan hasil yaitu dari total 46 responden didapatkan 16 responden $(34,8 \%)$ yang memiliki kebiasaan menggunakan las listrik yang baik. Hal ini karena pekerja memiliki kesadaran dan pengetahuan terhadap dampak yang dapat timbul pada kesehatan mata oleh karena itu memperhatikan memakai alat pelindung diri sesuai standar operasional prosedur kerja dan K3, pekerja las mengatakan dalam melakukan pengelasan diwajibkan dari setiap pekerja harus memakai alat pelindung diri agar terhindar dari resiko kecelakaan baik yang nampak maupun yang tidak terlihat seperti sinar inframerah atau radiasi. Melakukan pengelasan dalam waktu yang lama tanpa ada jangka waktu istirahat dapat menyebabkan mata terasa lelah dan pandangan kabur. Saat penelitian dilakukan beberapa responden penglihatan masih dalam keadaan normal pada pekerja yang belum lama bekerja sebagai pekerja las dan sering memeriksakan mata.

Menurut (Astna et al., 2019) Seseorang yang mempunyai pengetahuan yang tinggi cenderung akan melakukan suatu pekerjaan dengan berbagai pertimbangan yang bertujuan untuk meminimalisir resiko dari pekerjaan tersebut. Pada pekerja terdapat salah satu unsur penting yang harus di ketahui yaitu dampak dari sinar yang di pancarkan dari pengelasan yang bisa menyebabkan berkurangnya daya penglihatan. Dengan pengetahuan yang baik maka setiap pekerja akan terhindar dari pancaran langsung sinar dari pengelasan dengan memakai kacamata las.

2. Penurunanan Ketajaman Penglihatan

Dari hasil penelitian ini menunjukan distribusi responden sebagai berikut, dari total 46 responden didapatkan 38 orang responden $(82,6 \%)$ yang memiliki penurunan ketajaman penglihatan. Hal ini kemungkinan disebabkan oleh faktor lain yang mempengaruhi dapat berasal dari lingkungan internal atau eksternal. Faktor internal seperti genetik, usia, jenis kelamin, sedangkan faktor eksternal seperti bekerja dengan menatap objek secara dekat, radiasi, pola makan yang tidak sehat, waktu kegiatan diluar atau kegiatan olahraga yang sedikit. Pekerja las mengatakan bekerja terlalu lama dengan menatap objek saat melakukan pengelasan terlalu dekat dapat membuat mata seperti perih di malam hari, mata sering tidak fokus menatap objek dan terasa ada pembiasan pada mata saat melihat seperti warna abu-abu tetapi durasi tidak lama dan sehubungan dengan bertambahnya usia dan lama kerja beberapa pekerja mengalami penurunan namun belum melewati garis kuning saat diobservasi, jarak mata menggunakan las normal $15-25 \mathrm{~cm}$ jarak pandang mata dengan busur listrik menatap objek dengan memakai alat pelindung diri. beberapa pendapat dari pekerja las mengatakan saat pengelasan terdapat debu asap dan pajanan sinar las serta patikel besih yang biasa masuk ke mata yang dapat mengganggu proses dalam pengelasan.

Menurut (Mumtaza, n.d.) Penurunan ketajaman penglihatan dipengaruhi oleh kemampuan mata untuk berakomodasi. Pada usia 45 tahun manusia akan mengalami penurunan kemampuan berakomodasi sehingga tidak bisa melihat benda dalam jarak yang dekat. 
Menurut (Goldschmidt \& Jacobsen, 2014) mengatakan Penurunan ketajaman penglihatan adalah ketidakmampuan mata dalam melihat objek secara jelas dan sangat tergantung pada kemampuan akomodasi mata. ketidakseimbangan mentabolisme ini menyebabkan perubahan pada lensa atau pertumbuhan sclera (elongasi aksial). Kromosom yang terdapat dalam gen dapat menentukan pertumbuhan dari panjang aksila bola mata dan potensi myopia atau gangguan refraksi.

Pada distribusi frekuensi responden berdasarkan penurunan ketajaman penglihatan di dapatkan hasil dari total 46 responden didapatkan 8 responden $(17,4 \%)$ yang memiliki ketajaman penglihatan normal. Hal ini disebabkan karena adanya kesadaran pekerja dalam memakai alat pelindung diri itu sangat penting. Pemakaian alat pelindung diri sangat perlu untuk menghindari resiko kecelakaan dan gangguan pada kesehatan mata. Ketidakrutinan pekerja las dalam memakai kaca mata las mengakibatkan mata pekerja las terpapar secara langsung oleh sinar tampak, sinar inframerah serta sinar ultra violet. Akibat dari pemajanan secara langsung oleh sinar-sinar yang bersifat radiasi tersebut dapat mengakibatkan keluhan penglihatan pada pekerja las.

Beberapa pekerja masih dalam keadaan normal karena belum lama kerja dan keteliti dalam bekerja, dapat mengerti bahaya yang timbul saat menggunakan las, kemampuan akomodasi mata yang masih dalam keadaan baik dan memperhatikan prosedur yang ditetapkan di tempat kerja.

Ketajaman penglihatan bergantung pada berbagai faktor fisiologi seperti fokus retina, kepekaan saraf, dan kemampuan interpretative otak (Mumtaza, n.d.).

3. Hubungan kebiasaan menggunakan las listrik dengan penurunan ketajaman penglihatan di Kabupaten Toraja Utara Tahun 2021.

Berdasarkan hasil penelitian menunjukan bahwa dari 46 responden yang memiliki kebiasaan menggunakan las listrik yang buruk sebanyak 30 responden $(65,2 \%)$ yang terdiri dari 25 responden $(54,3 \%)$ yang memiliki penurunan ketajaman penglihatan yang buruk. Hal ini disebabkan karena pekerja yang tidak disiplin bahkan ada beberapa yang tidak menggunakan alat pelindung diri. Alasan pekerja tidak memakai alat pelindung dikarenakan ketidaknyamanan dalam bekerja. Selama proses pengelasan akan timbul cahaya dan sinar yang dapat membahayakan pekerja las. Cahaya tersebut meliputi cahaya yang dapat dilihat atau cahaya tidak tampak seperti Sinar Ultraviolet, radiasi dan Sinar Inframerah. terlalu lama dengan menatap objek saat melakukan pengelasan terlalu dekat dapat membuat mata seperti perih di malam hari, mata sering tidak fokus menatap objek dan terasa ada pembiasan pada mata saat melihat seperti warna putih abu-abu tetapi durasi tidak lama serta bertambahnya usia dan lama kerja.

Sebagaimana pendapat (Larik et al., 2016) bahwa paparan gelombang elektromagnetik menyebabkan perubahan pada protein lensa sehingga merubah struktur sel epitel pada lensa kerusakan pada enzim glutation peroksidase, yang bersifat sebagai pelindung lensa dari paparan radiasi.

Berdasarkan pemaparan di atas, maka dapat disimpulkan bahwa pemakaian alat pelindung diri sangat mempengaruhi keselamatan kerja dan kesehatan mata dan kecelakaan di lingkungan kerja.

Sementara distribusi responden dengan kebiasaan menggunakan las listrik yang buruk dengan ketajaman penglihatan normal terdapat 5 responden $(10,9 \%)$. Hal ini disebabkan karena belum adanya keluhan yang dirasakan selama bekerja sebagai pekerja las dan masa bekerja yang belum lama. Ketajaman akomodasi penglihatan masih dalam keadaan normal, pemakaian las listrik yang tidak terlalu lama.

Selain itu (Ramamurthy et al., 2015) mengatakan bahwa pekerja las pastinya berpotensi menimbulkan bahaya kecelakaan, baik jangka pendek maupun jangka panjang, begitu juga pada proses pengelasan, potensi bahaya yang dapat muncul. Hal tersebut terjadi karena kepekaan mata saat bekerja masih dalam keadaan yang baik dan belum ada gangguan dalam masalah penglihatan. 
Responden yang memiliki kebiasaaan menggunakan las listrik yang baik sebanyak 16 responden $(34,8 \%)$ yang terdiri dari 13 responden $(28,3 \%)$ yang memiliki penurunan ketajaman penglihatan. Hal ini kemungkinan disebabkan oleh faktor lain yang dapat mempengaruhi ketajaman penglihatan seperti ada riwayat myopia dan gangguan refraksi genetik dalam keluarga, umur, efek radiasi saat bekerja. faktor lain yang mempengaruhi bisa saja dapat berasal dari lingkungan internal atau eksternal. Faktor internal seperti genetik, usia, jenis kelamin, sedangkan faktor eksternal seperti Bekerja dengan menatap objek secara dekat, radiasi, Pola makan yang tidak sehat, waktu kegiatan diluar atau kegiatan olahraga yang sedikit. Pekerja las mengatakan bekerja terlalu lama dengan menatap objek saat melakukan pengelasan terlalu dekat dapat membuat kelelahan pada mata atau masalah pada ketajaman penglihatan.

Hasil penelitian yang sejalan dengan penelitian ini menunjukkan adanya perbedaan kejadian gangguan kesehatan mata antara pekerja yang disiplin dengan yang tidak. Bahwa semakin disiplin pekerja memakai APD semakin rendah pula prevalensi gangguan kesehatan mata (Pratiwi, 2014).

Pememakai alat pelindung diri saat pengelasan dapat mengurangi resiko terjadinya penurunan ketajaman penglihatan dari pada pekerja yang mengabaikan alat pelindung diri, pekerja las yang memiliki kesadaran dan mengetahui dampak baik buruknya yang bisa menyebabkan masalah pada mata dan mematuhi prosedur yang di tetapkan dan keselamatan, kesehatan, keselamatan kerja dalam dunia industry informal

Sementara distribusi responden memiliki kebiasaan menggunakan las listrik yang baik terdapat 3 responden $(6,5 \%)$ yang memiliki ketajaman penglihatan. Hal ini disebabkan karena keadaan ketajaman penglihatan mata masih dalam keadaan normal dan belum ada keluhan yang dirasakan. penglihatan masih dalam keadaan normal pada pekerja yang belum lama bekerja sebagai pekerja las dan sering memeriksakan mata. Kesadaran pekerja dalam memakai alat pelindung diri itu sangat penting, guna mencegah terjadinya penyakit akibat kerja yang muncul dikemudian hari. Pekerja las mengatakan selesai kerja dari workshop, pulang ke rumah membersihkan diri dan mencuci muka dengan air yang bersih sehingga partikel-partikel kecil atau debu yang masuk kedalam mata tidak menimbulkan sakit atau perih. memakai obat tetes mata untuk mengurangi masalah pada mata seperti mata merah atau kelilipan sehingga mata dalam keadaan baik saat bekerja.

Menurut penelitian (Astna et al., 2019) dijelaskan bahwa seseorang yang mempunyai pengetahuan yang tinggi cenderung akan melakukan suatu pekerjaan dengan berbagai pertimbangan yang bertujuan untuk meminimalisir resiko dari pekerjaan tersebut. Pemeriksaan mata sangat penting untuk mengetahui masalah pada mata yang harus diperhatikan untuk meminimalisir kejadian pada kesehatan mata baik fisik, jasmani, produktif dalam beraktivitas.

\section{KESIMPULAN}

Penelitian ini dilakukan di Kabupaten Toraja Utara yang dilaksanakan pada tanggal 01 April - 30 Mei 2021 mengenai hubungan kebiasaan menggunakan las listrik dengan penurunan ketajaman penglihatan pada pekerja bengkel las di Kabupaten Toraja Utara Tahun 2021 berdasarkan criteria penelitian. Dari hasil penelitian ini maka peneliti menarik kesimpulan: 1) kebiasaan menggunakan las listrik di Kabupaten Toraja Utara Tahun 2021 adalah responden yang memiliki kebiasaan menggunakan las listrik yang baik sebanyak 16 responden $(34,8 \%)$ dan responden kebiasaan menggunakan las listrik yang buruk sebanyak 30 responden $(65,2 \%)$. 2) penurunan ketajaman penglihatan di Kabupaten Toraja Utara Tahun 2021 adalah responden yang memiliki ketajaman 
penglihatan normal sebanyak 8 responden $(17,4 \%)$ dan responden penurunan ketajaman penglihatan sebanyak 38 responden $(82,6 \%)$. 3) untuk kebiasaan menggunakan las listrik, diperoleh nilai $p=0,859$, dimana $p>\alpha$ Ha ditolak Ho diterima yang berarti tidak ada hubungan kebiasaan menggunakan las listrik dengan penurunan ketajaman penglihatan pada pekerja bengkel las di Kabupaten Toraja Utara Tahun 2021.

\section{BIBLIOGRAFI}

Astna, A., Muliawati, R., \& Widjasena, B. (2019). Pemakaian Kacamata Las Menurunkan Visus Mata Pekerja Las. Jurnal Kesehatan Masyarakat Indonesia, 13(2), 13-16.

Fazriah, A. (2018). Hubungan Dukungan Sosial Dengan Tingkat Depresi Pada Lansia Di Balai Perlindungan Sosial Tresna Werdha (Bpstw) Ciparay Bandung. Universitas' Aisyiyah Bandung.

Goldschmidt, E., \& Jacobsen, N. (2014). Genetic and environmental effects on myopia development and progression. Eye, 28(2), 126-133.

Hidayat, A. A. (2015). Metode penelitian kesehatan paradigma kuantitatif. Health Books Publishing.

KemenKes, R. I. (2013). Riset kesehatan dasar (Riskesdas) 2013. Jakarta: Badan Penelitian Dan Pengembangan Kesehatan Kementrian Kesehatan Republik Indonesia.

Larik, R. S. A., Mallah, G. A., Talpur, M. M. A., Saeed, A., Ali, F., Larik, A. K. S., \& Karim, S. (2016). Adverse Effects of Cell Phone Radiation on Human Health. International Journal of Scientific Engineering Research, 7(10), 480-486.

Mumtaza, H. I. (n.d.). Perbedaan Tajam Penglihatan berdasarkan Pola Penggunaan Gadget pada Siswa Sekolah Menengah Pertama Negeri 2 Jember.

Munadar, A., \& Khairani, K. (2016). Gambaran Penglihatan Lanjut Usia Di Unit Pelaksana Teknis Dinas Banda Aceh. Jurnal Ilmiah Mahasiswa Fakultas Keperawatan, 1(1).

Munarko, H. (2012). Alat peraga rem angin.

Pratiwi, Y. S. (2014). Gangguan Kesehatan Mata pada Pekerja Las Listrik di Bengkel Las Listrik Desa Sempolan, Kecamatan Silo, Kabupaten Jember.

Priyanto, P., \& Tarwaka, Pgd. (2016). Hubungan Tingkat Kedisiplinan Pemakaian Alat Pelindung Mata Dengan Gangguan Kesehatan Mata Pada Pekerja Las Home Industry Di Kartasura. Universitas Muhammadiyah Surakarta.

Rakasiwi, D. W., \& Kep, K. S. (2019). Gambaran Umum Keluhan Fisik yang Dialami Lanjut Usia di Desa Karangasem Kecamatan Laweyan Kota Surakarta. Universitas Muhammadiyah Surakarta.

Ramamurthy, D., Lin Chua, S. Y., \& Saw, S. (2015). A review of environmental risk factors for myopia during early life, childhood and adolescence. Clinical and Experimental Optometry, 98(6), 497-506.

RI, K. (2016). Kementerian Kesehatan Republik Indonesia. 2018. Pedoman Umum Gizi Seimbang. Jakarta (ID): Direktorat Jenderal Bina Kesehatan Masyarakat.

Westheimer, G. (2010). Visual acuity and hyperacuity. Handbook of Optics, 3, 1-4.

(C) 2021 by the authors. Submitted for possible open access publication under the terms and conditions of the Creative Commons Attribution (CC BY SA)

license (https://creativecommons.org/licenses/by-sa/4.0/). 